\title{
Foreign Direct Investment (FDI) and its Impact on Hotel and Tourism Services in India
}

\author{
A. Muthusamy, Aravindaraj. K
}

\begin{abstract}
The Foreign Direct Investment (FDI) is required for a country, when domestic capital is inadequate for the purpose of enhancing economic growth. India needs substantial foreign capital inflows to achieve the economic growth and development. In an emerging economy like India, the Hotel \& Tourism services contributes significantly to the country's GDP as well as Foreign Exchange Earnings (FEE). India has significant potential to become a preferred tourist destination globally. Its rich and diverse cultural heritage, abundant natural resources and biodiversity provides numerous tourist attractions. Since 1991, Foreign Direct Investment (FDI) to the developing countries has been the leading source of external financing and has become a key component of national development strategies for almost all the developing countries in the world. Foreign Direct Investment up to 100 percent is allowed in Hotel and Tourism sector under Automatic route. The contribution of FDI in Hotel \& Tourism sector is stimulating the economic growth or not, this knowledge thrust of researcher creates the interest in conducting this study. In this paper, an attempt is made to review the concept of FDI and its impact on the Hotel \& Tourism sector in India. The study is based on only secondary sources of data and it covers for the period of recent ten years. The study shows a positive correlation between Foreign Direct Investment Equity inflows and Foreign Exchange Earnings (FEE) and Gross Domestic Product (GDP) of Hotel \& Tourism sector in India during the period of the study.
\end{abstract}

Keywords : Foreign Direct Investment, Economic Growth, Host Countries, Home Countries, Foreign Exchange Earnings, Gross Domestic Product.

\section{INTRODUCTION}

Foreign Direct Investment (FDI) to developing countries in the 1990s has been the leading source of external financing and has become a key component of national development strategies for almost all the countries in the world as a vehicle for technology flows and an important source of non-debt inflows for attaining competitive efficiency by creating a meaningful network of global interconnections. FDI provide opportunities to host countries to enhance their economic development and opens new opportunities to home countries to optimize their earnings by employing their ideal resources. The hotel and tourism sectors have been growing rapidly in recent years, bringing in huge revenues through overseas as well as domestic tourism. Tourism is the third largest revenue generators of foreign exchange for India and also employs one of the highest numbers in manpower.

Revised Manuscript Received on September 25, 2019

Dr. A. Muthusamy, Assistant Professor of Commerce, Padmavani Arts $\&$ Science College for Women, Salem

Aravindaraj. K*, Adjunct Faculty and Doctoral Research Scholar (PT), Department of Logistics Management, Alagappa University, Karaikudi

\author{
Meaning of Foreign Direct Investment (FDI)
}

FDI means investment made by non-resident entity/person resident outside India in the capital of an Indian company under Schedule 1 of Foreign Exchange Management (Transfer or Issue of Security by a Person Resident outside India) Regulations 2000. An Indian company may receive Foreign Direct Investment under the Automatic Route and Government Route.

\section{Meaning of Hotel \& Tourism}

The term hotels include restaurants, beach resorts, and other tourist complexes providing accommodation and/or catering and food facilities to tourists. Hotels are an important component of the tourism product. Tourism related industry include travel agencies, tour operating agencies and tourist transport operating agencies, units providing facilities for cultural, adventure and wild life experience to tourists, surface, air and water transport facilities to tourists, leisure, entertainment, amusement, sports, and health units for tourists and Convention/Seminar units and organizations.

\section{FDI Limit and Entry Route}

With a view to stimulate the foreign investments in this sector, the government has permitted 100 percent FDI in the automatic route -allowing full FDI into all construction development projects including construction of hotels and resorts, recreational facilities, and city and regional level infrastructure.

FDI in Indian Tourism Services

Foreign direct investment in tourism is a category of foreign investment whereby an entity resident in one economy acquires a lasting interest in a tourism specific enterprise engaging in tourism growth fixed capital formation (a direct investment enterprise) resident in an economy other than that of direct investor (UNWTO,2004, 22).

\section{RESEARCH PROBLEM}

The Indian tourism sector is one of the largest service industries in the country in terms of its contribution to the gross domestic product, 
foreign exchange earnings as well as providing employment. Tourism in India is witnessing widespread growth on the back off increasing outbound tourism by the growing middle class, rising inflow of foreign tourist and successful government campaigns for promoting 'Incredible India'. Foreign direct investment (FDI) helps to overtake the problem of low capital, low growth rate, untapped natural and human resources, high rate of inflation, unemployment, balance of payment and other structural and administrative rigidities. It is the reason most of the countries, especially developing countries like India are battling for attracting more and more foreign direct investment (FDI). Hence, this study is pertinent to analyse the impact of FDI inflows in the economic development of India.

\section{RESEARCH METHODOLOGY}

The present study is of analytical nature and makes use of secondary data. The analysis of the data forms the core part of the research. In order to analyse the data and draw conclusions, various statistical tools like growth rates and correlation have been used through Excel and SPSS Software. The study period was recent ten years, starting from the year 2009-10 to 2018-19.

\section{OBJECTIVES OF THE STUDY}

$>$ To analyse the concept of Foreign Direct Investment on the Hotel \& Tourism services;

$>$ To assess the impact of the Foreign Direct Investment on the Hotel \& Tourism services of India

\section{REVIEW OF EXISTING LITERATURE}

The aspects of foreign direct investment scenario and trends are analysed by most of the studies and they are,

Padmasree. $K$ and Bharathi Devi (2011) ${ }^{\mathbf{1}}$, studies the growth of foreign tourist arrivals and foreign exchange earnings into India through the Indian tourism industry. They also examine the share of the Indian Tourism Industry in the World in general and especially the Asia Pacific region.

Akhilesh Sharma et.al (2012) ${ }^{2}$, examines the foreign direct investment in Indian Tourism Industry, its flow in Indian Tourism Industry and its impact on economy of India. FDI plays a significant role in expanding the tourism sector in India. The Hotel \& Tourism industry provides tremendous opportunity to India in terms of contribution to its GDP and employment generation.

Rupal Patel $\mathbf{( 2 0 1 2 )}^{\mathbf{3}}$, traces the progress made by India's tourism industry in the planning era, and the emerging issues (like alternative tourism) under globalization. It examines the problems and challenges of the country as well as the pitfalls in tourism planning in India. He also makes some policy suggestions to address the constraints in promoting sustainable tourism in India.

Niranjana. C and Vimya K.P (2013) ${ }^{\mathbf{4}}$, analyze the foreign investment in India's tourism sector. Tourism sector holds immense potential for Indian economy. It can provide impetus to other industries through backward and forward linkages and can generate huge revenue earnings for the country. The importance of tourism as a source of foreign exchange for India cannot be ignored.

\section{ANALYSIS AND DISCUSSION}

Trends of Foreign Direct Investment (FDI) inflows into the Hotel and tourism services are studied under the following heads.

i. Number of Foreign Tourist Arrivals (FTA)

ii. Foreign Exchange Earnings (FEE)

i. FOREIGN TOURIST ARRIVALS (FTA)

Foreign Tourist Arrivals (FTA) refers to the number of arrivals of tourists/visitors from abroad. An individual who makes multiple trips to the country is counted each time as a new arrival. A foreign tourist is a person visiting India on a foreign passport, staying at least twenty four hours in the country, for the following purposes.

(i) Leisure (recreation, holiday, health, study, religion and sport);

(ii) Business, family, mission, meeting.

\section{ii. FOREIGN EXCHANGE EARNINGS (FEE)}

Foreign Exchange Earnings from tourism are the receipts of the country as a result of consumption expenditure, i.e. payments made for goods and services acquired, by foreign visitors out of the foreign currency brought by them. The revenue through foreign exchange is analyzed in respect of growth of exchange earnings from tourism over a period of time and percentage of exchange earnings from tourism. Tourism is one of the important sectors in India for Foreign Exchange Earnings.

The year-wise amounts of Foreign Direct Investment (FDI) inflows, number of foreign tourist arrivals, and Foreign Exchange Earnings (FEE) of the hotel \& tourism services are provided in Table 1 
TABLE 1: FDI INFLOWS, FOREIGN TOURIST ARRIVALS (FTA), FOREIGN EXCHANGE EARNINGS (FEE) OF THE HOTEL \& TOURISM SERVICES

\begin{tabular}{|c|c|c|c|c|c|c|}
\hline Years & $\begin{array}{l}\text { FDI Inflows } \\
\text { (₹ In Crores) }\end{array}$ & $\begin{array}{l}\text { AGR } \\
(\operatorname{In} \%)\end{array}$ & $\begin{array}{c}\text { Foreign Tourist } \\
\text { Arrivals } \\
\text { (In Number) }\end{array}$ & $\begin{array}{l}\text { AGR } \\
(\text { In } \%)\end{array}$ & $\begin{array}{c}\text { Foreign Exchange } \\
\text { Earnings } \\
\text { (₹ In Crores) }\end{array}$ & $\begin{array}{l}\text { AGR } \\
(\operatorname{In} \%)\end{array}$ \\
\hline $2009-10$ & $3,542.43$ & - & $53,19,697$ & - & 56,497 & - \\
\hline 2010-11 & $1,462.18$ & -58.72 & $59,09,075$ & 11.08 & 68,065 & 20.48 \\
\hline 2011-12 & $4,753.89$ & 225.12 & $63,76,353$ & 7.91 & 81,815 & 20.20 \\
\hline $2012-13$ & $17,776.84$ & 273.94 & $66,75,209$ & 4.69 & 97,783 & 19.52 \\
\hline 2013-14 & $2,948.73$ & -83.41 & $71,45,476$ & 7.04 & $1,11,583$ & 14.11 \\
\hline 2014-15 & $4,875.12$ & 65.33 & $77,66,108$ & 8.69 & $1,26,288$ & 13.18 \\
\hline $2015-16$ & $8,761.18$ & 79.71 & $82,48,540$ & 6.21 & $1,40,635$ & 11.36 \\
\hline 2016-17 & $6,139.82$ & -29.92 & $90,83,059$ & 10.12 & $1,59,648$ & 13.52 \\
\hline $2017-18$ & $7,278.75$ & 18.55 & $1,03,81,277$ & 14.29 & $1,84,971$ & 15.86 \\
\hline 2018-19 & $7,589.76$ & 4.27 & $1,05,96,292$ & 2.07 & $1,95,266$ & 5.57 \\
\hline $\begin{array}{l}\text { CAGR } \\
(\operatorname{In} \%)\end{array}$ & 7.92 & - & 7.13 & - & 13.2 & - \\
\hline
\end{tabular}

Source: Department of Industrial Policy and Promotion (DIIP), Ministry of Tourism.

Table 1 shows the growth rate of Foreign Direct Investment (FDI) inflows during the period from 2009-10 to 2018-19. The amount of FDI inflows in the Hotel and tourism services has decreased from ₹ 3,542.43 crores in 2009-10 to ₹ $1,462.18$ crores in 2010-11. Even though the amount of FDI inflows declined to ₹ $1,462.18$ crores in $2010-11$, it has picked up in the subsequent years. The increase over the period was 2.14 times.

During the study period, the percentage of growth over the previous year lies between -83.41 percent and 273.94 percent. The highest growth rate of 273.94 percent has been observed in the year 2012-13. The negative growth rate of -83.41 percent has been observed in the year 2013-14.

The Compound Annual Growth Rate (CAGR) of amount of FDI inflows was 7.92 percent which is a good sign of growth. During the study period of ten years, it has been observed that for five years the growth rate was above the CAGR and for four years the growth rate was below the compound annual growth rate.

Further the table shows the growth rate of foreign tourist arrivals in India during the period from 2009-10 to 2018-19. The number of foreign tourist arrivals has increased from $53,19,697$ in $2009-10$ to $1,05,96,292$ in $2018-19$. The increase over the period was 2 times.

During the study period, the percentage of growth over the previous year lies between 2.07 percent and 14.29 percent.
The highest growth rate of 14.29 percent has been observed in the year 2017-18. The lowest growth rate of 2.07 percent has been observed in the year 2018-19.

The Compound Annual Growth Rate (CAGR) of number of foreign tourist arrivals was 7.13 percent which is a welcome trend. During the study period of ten years, it has been observed that for five years the growth rate was above the CAGR and for four years the growth rate was below the compound annual growth rate.

Further the table exhibits the growth rate of Foreign Exchange Earnings (FEE) from Hotel and tourism services in India. The amount of foreign exchange earnings in the Hotel and tourism services has increased from ₹ 56,497crores in $2009-10$ to $₹ 1,95,266$ crores in 2018-19. The increase over the period was 3.45 times.

During the study period, the percentage of growth over the previous year lies between 5.57 percent and 20.48 percent. The highest growth rate of 20.48 percent has been observed in the year 2010-11. The lowest growth rate of 5.57 percent has been observed in the year 2018-19.

The Compound Annual Growth Rate (CAGR) of amount of foreign exchange earnings in Hotel and tourism services was 13.2 percent which is a welcome trend. During the study period of ten years, 
it has been observed that for six years the growth rate was above the CAGR and for three years the growth rate was below the compound annual growth rate.

\section{Testing of Hypotheses}

In order to substantiate the objectives, the following hypotheses have been formulated:

1. Null Hypothesis $\left(\mathbf{H}_{\mathbf{0}}\right)$ : There is no significant relationship between FDI inflows and Foreign Tourist Arrivals.

Alternate Hypothesis $\left(\mathbf{H}_{1}\right)$ : There is significant relationship between FDI inflows and Foreign Tourist Arrivals.
2. Null Hypothesis (H0): There is no significant relationship between FDI inflows and Foreign Exchange Earnings.

Alternate Hypothesis $\left(\mathbf{H}_{\mathbf{1}}\right)$ : There is significant relationship between FDI inflows and Foreign Exchange Earnings.

To test the above framed null hypothesis, a correlation co-efficient (Bivariate) has been undertaken. The results are furnished in the following Table 2.

\section{CORRELATION ANALYSIS}

Correlation is a measure of the linear relationship between two or more variables and its value always lies between the ranges -1 to +1 .

TABLE 2: CORRELATION COEFFICIENT (BIVARIATE) MATRIX OF FDI INFLOWS, FOREIGN TOURIST ARRIVALS AND FOREIGN EXCHANGE EARNINGS OF HOTEL \& TOURISM SECTOR

\begin{tabular}{|ll|c|c|c|}
\hline & FDI INFLOWS & $\begin{array}{c}\text { FOREIGN } \\
\text { TOURIST } \\
\text { ARRIVALS }\end{array}$ & $\begin{array}{c}\text { FOREIGN } \\
\text { EXCHANGE } \\
\text { EARNINGS }\end{array}$ \\
\hline FDIIF & Pearson Correlation & 1 & .197 & .229 \\
\hline \multirow{2}{*}{ FTA } & Sig.(2- tailed) & .586 & .524 \\
\hline \multirow{2}{*}{ FEE } & Pearson Correlation & .197 & 1 & $.995 * *$ \\
& Sig.(2- tailed) & .586 & .000 \\
\hline
\end{tabular}

**. Correlation is significant at the 0.01 level (2-tailed).

\section{Interpretation and Conclusion}

i. The correlation between FDI inflows and foreign tourist arrivals of hotel \& tourism service is .197 which reveals that there is a low correlation among the two variables and is statistically not significant as the p-value is greater than 0.05 .

ii. The correlation between FDI inflows and foreign exchange earnings of hotel \& tourism service is .229 which also reveals that there is a low correlation among the two variables and is statistically not significant as the $\mathrm{p}$-value is greater than 0.05 .

The correlation between the foreign tourist arrivals and foreign exchange earnings is .995 which emphasizes the strong correlation. It also confirms that the p-value between foreign tourist arrivals and foreign exchange earnings is .000 $(\mathrm{p}<0.05)$.

\section{FINDINGS OF THE STUDY}

$>$ During the period under study, it is observed that FDI inflows received by the Hotel \& tourism services in India shows an increasing and decreasing trend during the study period. However, it is an encouraging sign that the increase over the period was 2.14 times with the compound annual growth rate of 7.92 percent.

$>$ It is an encouraging sign that the number of foreign tourist arrivals has constantly increased throughout the study period. It has risen from 53,19,697 in 2009-10 to $1,05,96,292$ in $2018-19$ registering the CAGR of 7.13 percent.

$>$ There has been continuous increase observed in foreign exchange earnings of the Hotel \& tourism services during the study period.

$>$ It is apparent from the statistical analysis that correlation between foreign tourist arrivals and FDI inflows reveals that a low correlation of 0.197 ; the correlation between FDI inflows and foreign exchange earnings also signifies the low degree of correlation of 0.229 ; and the correlation between foreign tourist arrivals and foreign exchange earnings of the Hotel \& tourism service sector shows a strong correlation of 0.995 at $5 \%$ significance level.

\section{SUGGESTIONS}

$\checkmark$ Better infrastructure facilities, like, road 
lines, airports, accommodation facilities, drainage and sanitation facilities etc. need to be created immediately for faster tourism development

$\checkmark$ Tax holiday would encourage FDI in this sector and more players to set up hotels, to bridge the shortage of rooms which according to Government estimates stood at one lakh rooms.

$\checkmark$ Better services need to be provided to the international tourists and quality standards for providing services should be upgraded, which include readily accessible information guides / bulletins, stress-free arrivals, improved hygienic conditions in tourism sites and surroundings, clean railway stations and so on.

$\checkmark$ Tour operators, guides must develop a good relationship with tourists.

\section{EPILOGUE}

Tourism is the largest service industry globally in terms of gross revenue as well as foreign exchange earnings. It can play an important and effective role in achieving the growth with equity objectives which India has set. Tourism is one economic sector in India that has the potential to grow at a high rate and can ensure consequential development of the infrastructure of the destinations. The expansion of the tourism sector can lead to large scale employment generation and poverty alleviation. Tourism also encourages preservation of monuments and heritage properties and helps the survival of art forms, crafts and culture.

\section{REFERENCES}

[1] Secretariat for Industrial Assistance, (SIA): Various Newsletters, Annual Issue, Ministry of Commerce and Industry, Government of India, New Delhi.

[2] India Tourism Statistics, Annual reports,(From 2009 to 2019), Ministry of Tourism, Government of India, New Delhi.

[3] Padmasree. K and Bharathi Devi (2011), "The performance of the Indian Tourism Industry in the era of globalization -a conventional study", African Journal of Hospitality, Tourism and Leisure Vol. 1 (4), pp. 1-9.

[4] Akhilesh Sharma et.al (2012), "FDI: An Instrument of Economic Growth \& Development in Tourism Industry", International Journal of Scientific and Research Publications, Volume 2, Issue 10, pp. 1-6.

[5] Rupal Patel (2012), "India's Tourism Industry - Progress and Emerging Issues", Arth Prabhand: A Journal of Economics and Management, Vol.1 Issue 5, pp. 1-10.

[6] Niranjana. C and Vimya K.P (2013), "Foreign Direct Investment: An Exploration of Opportunities in Indian Tourism", International Journal of Management and Development Studies, Volume No. 2 (2013), Issue No. 12, pp.27-33.

[7] www.dipp.gov.in

[8] www.tourism.gov.in 